\title{
CAÑONES Y REMOS: LAS GALERAS DE FEDERICO SPÍNOLA EN LA ESTRATEGIA NAVAL ESPAÑOLA, 1593-1603
}

\author{
Asunción Retortillo Atienza \\ Universidad de Burgos
}

\begin{abstract}
RESUMEN. Tras el desastre de 1588, la política española contra Inglaterra se centró en poner en marcha diferentes planes destinados a frenar sus actividades por mar. Uno de estos proyectos fue el que Federico Spínola presentó en Bruselas a Esteban de Ibarra en 1593 proponiendo navegar por el Canal de la Mancha hostigando a los barcos holandeses e ingleses. En los memoriales presentados por el genovés, éste se comprometía a utilizar galeras para la defensa de los Países Bajos y para estorbar la navegación de los barcos ingleses y de las Provincias Unidas en la zona, cortando, de paso, el comercio entre ambas. Sin embargo, las necesidades estratégicas de Felipe II en el canal después de los ataques de la armada inglesa de 1596 le llevaron a negociar con Spínola un nuevo plan consistente en tomar un puerto inglés para frenar los ataques navales de la reina Isabel I.
\end{abstract}

Palabras clave: Federico Spínola, Felipe II, Armada española, Flandes, Isabel de Inglaterra

ABSTRACT. Following the 1588 disaster, Spanish policy against England focused on implementing various plans aimed at curbing its activities by sea. One of this project was that Federico Spínola presented in Brussels to Esteban de Ibarra in 1593 proposing to sail the English Channel harassing Dutch and English ships. In the memorials presented by the Genoese, he committed himself to using galleys for the protection of the Netherlands, and to hinder the navigation of English and the United Provinces ships in the area, by cutting off trade between them. However, Philip II's strategic needs in the Canal after the attacks of the English navy of 1596 led him to negotiate with Spínola a new plan to take an English port to stop Queen Elizabeth I.

Keywords: Frederick Spínola, Philip II, Spanish Navy, Flanders, Queen Elisabeth I

Recibido: 16-11-2020 . Aceptado: 16-03-2021 . aretortillo@ubu.es 
En Flandre allons-nous en, et comme généraux

Faisons-nous voir à tous, braves et valeureux

Pour servir ce grand Roy, ne craignons la furie,

Il nous rendra Seigneurs de toute Ligurie ${ }^{1}$

En ESTOS VERSOS DODECASílabos de un libelo publicado en La Haya en 1603 se establecía la estrategia seguida por los hermanos Federico y Ambrosio Spínola para obtener de la corona española el título de duques de Génova. Sin embargo, lo único cierto que hay en ellos es que el rey de España — si hubiese podido - les habría concedido el título por la necesidad que tenía de sus servicios.

En las últimas décadas del siglo Xvi la revuelta de parte de los Países Bajos, el enfrentamiento con los Borbones en Francia, la complicación progresiva de las relaciones con Inglaterra, así como la creciente actividad corsaria inglesa y holandesa entre el Atlántico norte y las islas Azores, hicieron que Felipe II focalizase su atención diplomática y militar en el Canal de la Mancha (Sáiz Cidoncha, 1985; Fernández Duro, 1973; Corbett, 1917; Cerezo Martínez, 1989; Ortega y Medina, 1994). El rey viró su centro de actividad marítima desde el Mediterráneo convirtiéndolo en el nuevo escenario de las operaciones de la Monarquía Hispánica (Fernández Álvarez, 1947, p. 5; Goodman, 2003, p. 3).

La corona española, en torno a 1580, sufrió duramente el embate de los barcos ingleses y holandeses, tanto en las costas de la Península Ibérica como en sus posesiones ultramarinas, complicando la singladura de los navíos y sus cargamentos. También atacaban a los barcos que navegaban por el Canal de la Mancha estrangulando la capacidad bélica del ejército español en la guerra de Flandes. Las dificultades del paso por el estrecho estorbaban las comunicaciones y el flujo de mercancías, soldados y dinero con los Países Bajos. Ello forzaba a utilizar el camino español que atravesaba Europa por tierra, mucho más largo y expuesto a incidentes. Esta ruta había sido utilizada de forma habitual desde el reinado de Carlos V, cuando no se podía disponer de Calais como puerto de resguardo de camino hacia el norte (Sicking, 2017). En este itinerario, desde que embarcaban las tropas en Barcelona o Cartagena hasta la llegada a Génova o La Spezia tardaban unos 10 días; luego se trasladaban por tierra hasta Milán y de allí hacia Bruselas en un viaje que duraba en total casi tres meses. Mientras que por mar desde A Coruña o Santander el traslado de tropas se realizaba en 40 días o menos si el tiempo era favorable (Fagel, 2001, pp. 363-376).

1 Vámonos a Flandes, y como generales / Hagámonos ver por todos, bravos y valerosos / Para servir a este gran Rey, no temamos la furia / Él nos hará señores de toda Liguria [Traducción de la autora], Anónimo, Prives devis, entre le marquis Spínola et son frère Federicq, pour l'agrandissement de leur maison, La Haya, 1603, Koninklijke Bibliotheek. 
Además, por un lado, los conflictos confesionales asociados a las circunstancias políticas de ambas monarquías contribuyeron a que Inglaterra se convirtiese para Felipe II en el objetivo principal de su estrategia ofensiva en todos los ámbitos. Por otro lado, un nuevo elemento elevó los niveles de confrontación entre ambas coronas: el apoyo que la reina Isabel de Inglaterra prestó a Holanda y Zelanda alentando sus aspiraciones de independencia ${ }^{2}$. Los acuerdos de apoyo mutuo que se establecieron entre ingleses y rebeldes holandeses y zelandeses frente a su enemigo común eran de conocimiento público. Desde que los «mendigos del mar» se hicieron con los puertos de Vlesinga y Brielle en 1572 — inspirados por la reina y su ministro Burghley-, Inglaterra disponía de guarniciones situadas en estos puertos de la costa zelandesa. Su colaboración era tan estrecha que Isabel I recibió en enero de 1576 el título de condesa de Holanda; aunque el título fue rechazado debido a sus objeciones personales sobre los derechos legales a la expansión territorial de un Estado (Adams, 2004, p. 309; Ortega y Medina, 1994, cap. 5, p. 38; Armitage, 2000, p. 6; Harding, 2006, pp. 20-38).

Sin embargo, el año de 1584 supuso un punto de inflexión en las relaciones entre Inglaterra y las provincias sublevadas. El 10 de junio falleció Francisco de Anjou, hijo del Enrique II de Francia y Catalina de Medicis, al que Guillermo de Nassau estatúder de Holanda, Zelanda y Utrecht - había ofrecido cuatro años antes el trono de las Provincias Unidas tras el rechazo de la reina inglesa (Duquenne, 1998, p. 380). Un mes después el propio Guillermo fue asesinado en su palacio de Delft. Ambas muertes crearon un vacío político momentáneo en las mencionadas provincias que fue aprovechado por Isabel de Inglaterra, quien se había percatado de que se había aprovechado de la influencia perdida al otro lado del Canal por sus reparos morales Francia. Por ello, en esta nueva oportunidad, se presentó ante los Estados Generales de las Provincias Unidas como el mejor aliado posible frente a la Monarquía Hispánica; su apoyo fue aceptado rápidamente ya que las negociaciones iniciadas con Francia para coronar un nuevo rey de la familia Anjou no prosperaron por las excesivas demandas francesas (Shaw, 1936, p. 7). Estos sucesos, entre otros, propiciaron el acercamiento entre Felipe II y los Valois, que era una de las circunstancias a las que más temía la reina Tudor, puesto que Francia era el elemento que equilibraba la balanza tradicional de poderes en el noroeste de Europa en ese momento (Martínez Millán, de Carlos, 1998, p. 252).

La historiografía anglosajona ha escrito abundantemente sobre el cambio sufrido en las intenciones de la reina de Inglaterra con respecto a las Provincias Unidas en estos años (Parker, 2002; MacCaffrey, 1981). Los historiadores más recientes se inclinan a pensar que Isabel se percató de que ayudar a las Provincias Unidas y ba-

2 Sobre las estrechas relaciones entre ingleses y rebeldes más allá de las cuestiones políticas véase Dunthorne (2013). 
tallar en suelo extranjero era la mejor forma de hacer la guerra a Felipe II (Adams, 1998, p. 19-31). Tras el acercamiento que se produjo en las relaciones hispano francesas, la reina de Inglaterra entendió que la confrontación militar sería ineludible y estaba cada vez más próxima. Esta idea se vio acrecentada por las reiteradas noticias que llegaban a Londres sobre la preparación de una flota española para invadir la isla. Por ello, su decisión de intervenir en el conflicto de los Países Bajos estuvo más influenciada por la necesidad de hacer frente a la amenaza que suponía la Monarquía Hispánica y su ejército al otro lado del Canal que por solucionar el problema de la revuelta holandesa. De ahí que, en marzo de 1585, Isabel encargase a William Davison, su agente en las Provincias, informar a los Estados Generales de su oferta de protección frente a España a cambio de las ciudades de Vlessinga, el fuerte de Rammekens, Brielle y Enckhuisen; todas ellas eran ciudades portuarias estratégicamente situadas a lo largo de la costa de las provincias de Holanda y Zelanda controladas ya, indirectamente, por Inglaterra. Los Estados Generales aceptaron de buen grado el favor de la reina de Inglaterra y declararon, incluso, que no habría ninguna dificultad en ofrecerle cualquier plaza que ella desease en Holanda (Shaw, 1936, p. 8).

Las conversaciones posteriores se concretaron el 10 de agosto de 1585 cuando los nuevos Estados Generales de las Provincias Unidas firmaron con Inglaterra el Tratado de Nonsuch. Además de ceder varias plazas, recibirían ayuda económica y militar inglesa bajo la figura legal del protectorado (Shaw, 1936, p. 13; Sanz Camañes, 2007, p. 124). La reina Isabel publicó y distribuyó un escrito panfletario a modo de justificación de sus razones sobre el cambio de política titulado «A declaration of the causes moving the Queen of England to give aid to the defence of the people afflicted an oppressed in the Low Countries» (Wallace, 1916, p. 338-340; Wagner , 2019, p. 178-180). El documento, que se imprimió en inglés, francés, italiano y flamenco, en un claro afán propagandístico, no era una declaración de guerra contra la corona española pero se le aproximaba bastante (Graham, 1972, p. 58; Oosterhoff, 1967, p. 60); aunque, de forma interna, Inglaterra no estaba especialmente contenta con la relación de dependencia que las Provincias Unidas habían establecido con ellos y el coste de la misma (Borman, 1997, p. 307).

Desde Londres, París y La Haya llegaban puntualmente a la corte española noticias de todos estos movimientos que terminaron por convencer al rey de que el enfrentamiento con Inglaterra era inevitable (Sanz Camañes, 2012, p. 103; Parker, Martin, 1999, p. 203). Esta idea se reforzaba con la llegada a los consejos de Estado, Guerra y Hacienda de memoriales y ofertas de diversas personas con la intención de detener los avances ingleses planteando posibles empresas para ello. El duque de Parma también envió desde Bruselas el 20 de abril de 1586 una carta muy extensa en la que detallaba en veinte puntos un proyecto para invadir Inglaterra; este documento era la versión simplificada de otro anterior de don Juan de Austria. En él proponía 
enviar allí tropas veteranas de Flandes en barcos de fondo plano acompañados de otros barcos de guerra. Los 30.000 hombres y 500 caballos propuestos podían estar en Essex o Kent en ocho o diez horas (Graham, 1972, p. 62). Sin embargo, aunque los auténticos motivos del rey e incluso el relato de los sucesos del verano de 1588 varían entre las diversas corrientes historiográficas (García Hernán, 1989; Sanz Camañes, 2017; Illik, 2018), una vez tomada la decisión de atacar, Felipe II no desechó totalmente ese plan, pero lo combinó con otro planteado por el marqués de Santa Cruz de agrupar un elevado número de tropas y barcos para llegar a la isla de Gran Bretaña desde la península. En Flandes, para esta Gran Armada, el duque de Parma reunió en 1587 y los primeros meses de 1588 una flotilla de 300 barcos; sin embargo, la falta de órdenes directas en el último momento hizo que, finalmente, los barcos alistados por Alejandro Farnesio no participasen en los planes de ataque a Inglaterra (Stradling, 1992, p. 233; Parker, 1976, p. 359).

El desastre de la Armada preparada en $1588^{3}$ supuso la paralización momentánea de la actividad marítima española en el norte debido a la importante pérdida de barcos sufrida. En Inglaterra, sin embargo, con la población preparada para hacer frente al ataque español, la escasez de batalla produjo una sensación de extraña ansiedad tanto entre los ingleses como en la gran cantidad de exiliados procedentes de los Países Bajos que vivían en Londres. En palabras de Hume «los ociosos reacios a volver a trabajar, los turbulentos jóvenes que ardían por una excusa para ir a por alguien y los ricos señores que estaban sedientos de lucha clamaron por venganza y represalias» (1896, p. 9). En Holanda incluso se acuñaron monedas conmemorativas de la pérdida de la Armada española, donde se representa a la reina inglesa en el carro de la victoria, llevando en sus manos el libro de las oraciones dominicales en flamenco (Dugniolle, 1877, p. 95). Isabel, que no era ajena a la frágil protección naval de las costas ibéricas, aprovechó el impulso de los preparativos de defensa que se habían hecho ese año, y la inesperada ventaja obtenida, para tratar de acabar con el poder español en el mar. Consiguió reunir una flota de 180 barcos con el objetivo de explotar la debilidad de Felipe II. Con ellos, en lo que se ha denominado «la contraarmada», intentó atacar los puertos españoles que cobijaban las mejores naos y los principales astilleros sin mucho éxito ${ }^{4}$. También apoyó al nuevo rey de Francia, Enrique de Borbón, en su lucha contra Felipe II prestándole 881.867 florines entre 1587 y 1589 (Shaw, 1936, p. 46). Por otro lado, la corona española en su conflicto con los rebeldes del norte y los «mendigos del mar», había hecho varios intentos de reunir una armada para hacerles la guerra por mar en 1573-1574 pero estos fracasaron por diferentes

3 Un análisis historiográfico en Sanz Camañes (2012, pp. 17-29).

4 Biblioteca Nacional de España (en adelante BNE), Manuscrito 18579, f. 8. Relación de lo subçedido de la armada enemiga del reyno de Ynglaterra... este año de 1589; véase también Saavedra Vázquez (1989 y 1998). 
motivos. Los holandeses aprovecharon esa oportunidad para hacerse con la mayor parte de los puertos de Flandes tomado la delantera en este campo (Stradling, 1992, p. 28; Riaño, 1999, p. 71-76).

La reacción española al avance inglés en el Canal fue muy lenta y se tardó más de lo necesario en reparar en las consecuencias perjudiciales de la ausencia de una marina de guerra en la lucha contra las provincias sublevadas (Pollentier, 1959, p. 160). Prácticamente no se tomaron medidas hasta que en 1583 se refundó el Almirantazgo en los Países Bajos impulsado por Farnesio ${ }^{5}$. Sin embargo, esta institución sufrió muchas dificultades, tanto en su puesta en marcha como en su funcionamiento, que la convirtieron en inoperante. Las funciones del almirantazgo poseían una vertiente comercial y fiscal más que militar. Este organismo tenía por objeto facilitar el comercio de las provincias obedientes con las de la península y tenía competencias sobre todos los asuntos del mar del Norte: comercio, pesca, guerra, corsarios, licencias y pasaportes (Fernández Duro, 1973 p. 230; Aerts, Baelde, Coppens, p. 491). Esto siempre creó roces con las provincias por la recaudación de los derechos de pesca y los porcentajes de aduanas, el reparto de capturas, etc. Además, carecía de una organización específica propia y su estructura administrativa era similar a la del ejército de tierra (Lemaire, 1934, p. 164). Esta nueva institución se reveló como totalmente inoperante en lo que a capacidad bélica se refiere puesto que se centró en regular el comercio y su navegación marítima (Pollentier, 1959, p. 19); por otro lado, el almirante carecía de autonomía de gobierno ya que dependía de un consejo que era el que tenía la última palabra para todo; ambos, consejo y Almirantazgo, incluso tenían sedes diferentes: el primero en Amberes y el segundo en Dunquerque (Aerts, Baelde, Coppens, p. 488). Las reformas para hacerlo más útil se sucedieron sin éxito desde 1586 (Bolsée, 1991, pp. 6-16). En opinión de Pollentier (1959, p. 160) los orígenes de las dificultades en el almirantazgo se hallaban en que el almirante estaba totalmente sometido al consejo y las transformaciones de Farnesio habían reducido aún más sus competencias. Lo cierto es que desde los años noventa las disputas judiciales sobre la administración del almirantazgo detuvieron la actividad naval en los Países Bajos españoles y provocó que se relajase la disciplina entre los miembros de la armada (Stradling, 1992, p. 33) convirtiéndose en otra causa de la ausencia de una armada efectiva en Flandes. Aunque entre los objetivos del almirantazgo también estaba la defensa de los puertos de los Países Bajos, adolecía de una estrategia militar ofensiva entre sus responsabilidades lo que unido a sus dificultades de gobierno originó un vacío difícil de llenar en el conflicto con los rebeldes de las islas. Todo ello generó dos consecuencias directas: en Flandes no había barcos de guerra en número suficiente 
ni para defenderse y tampoco había puertos suficientes para contener los barcos necesarios en caso de construirse una armada eficiente ${ }^{6}$.

La ausencia de las naos que deberían haberse construido y mantenido en Flandes por el almirantazgo facilitó el tránsito sin oposición alguna de los barcos ingleses por el Canal en un momento esencial de su auge naval. La década de 1590 representó una fase decisiva de la lucha por la hegemonía en Europa y América en la que los ataques de corsarios ingleses se convirtieron en la forma característica de la guerra isabelina que dominó la guerra del mar (Andrews, 1964, chapter 1, p. 3). Entre 1591 y 1595 atacaron el imperio portugués tomando y saqueando Santa Elena, Santo Espíritu o Pernambuco. Y en 1596 nadie fue capaz de hacer frente a la armada inglesa que asoló a sus anchas diversos puntos de la costa española llegando a secuestrar Cádiz durante quince días. A su vuelta a Londres, los marineros ingleses se jactaban de que si hubieran tenido vituallas habrían podio marchar con facilidad hasta Madrid porque el poder del rey de España había quedado muy enflaquecido ${ }^{7}$.

Desde el punto de vista estratégico, para la corona española había quedado claro que la lucha contra la reina Isabel, los hugonotes franceses y los rebeldes holandeses pasaba por controlar el espacio marítimo del Canal. Para ello, la principal acción en el Atlántico norte era el envío de otra armada contra Inglaterra. Una vez superada la decepción de 1588, la «política de armadas» iniciada por Felipe II en la década de los noventa puso en marcha un programa de reconstrucción naval que produjo en los años siguientes nuevos galeones (Stradling, 1992, p. 32) e impulsó el envío de armadas españolas a Irlanda e Inglaterra en 1596 y 1597 (Tenace, 2003, p. 860). Ninguna de estas dos llegó a término porque, entre otras causas, nuevamente las tormentas del Atlántico dispersaron las flotas. Por el contrario, las exitosas campañas por tierra en Francia tanto del duque de Parma como del archiduque Alberto - que tomó las fortalezas de La Vère, Calais y Ardres a los franceses y Hulst a los rebeldes - permitieron a las tropas españolas controlar la costa meridional del estrecho posibilitando en esas fechas un nuevo impulso a la guerra marítima española en el norte ${ }^{8}$. De hecho, ya hacía varios años que Francis Drake había avisado a Isabel Tudor que se debería temer mucho más a los barcos del duque de Parma que a los de Medinasidonia (Wernham, 1994, p. 1).

La toma española del puerto de Calais en abril de 1596 y la contrariedad que engendraron en la corte de Londres los éxitos militares del ejército de Flandes afianzaron la voluntad inglesa de limitar los avances de España en torno al Canal; con esta

6 Archive Général du Royaume (en adelante AGR), Audience, 1464-2, sin foliar (sf). Memorial de Federico Spínola circa 1593.

7 Archivo General de Simancas (en adelante AGS), Estado, 612, f. 80, Avisos de Londres, 25 de agosto de 1596.

8 AGS, Estado, 613, f. 48, Bruselas, 14 de marzo de 1597. 
perspectiva Isabel propició acuerdos con Francia y las Provincias Unidas firmando el Tratado de Greenwich y creando la Triple Alianza contra la corona española (Wernham, 1994, pp. 69-81; De Buzanval, 1846, p. 368-377; Saint-Prest, 1720, pp. 252 y 331$)^{9}$. Esta escalada de tensiones en torno al estrecho hizo más férrea la decisión de Felipe II de centrarse en luchar por tierra contra los rebeldes, para no perder los Países Bajos, incrementando el envío de fondos y la recluta de soldados; ello permitió a Inglaterra concentrar sus esfuerzos en reprimir la rebelión de Irlanda y en reforzar la ofensiva por mar contra España tanto en la península como en sus territorios americanos (Wernham, 1994, p. 69).

\section{El proyecto de Federico Spínola en el Canal de la Mancha}

Pero además de las armadas preparadas por la corona española en 1596 y 1597 , Felipe II puso en marcha otros proyectos destinados a invadir Inglaterra de todos los que circularon por los consejos enviados por políticos, economistas y mercaderes con este objetivo ${ }^{10}$. De hecho, el rey redactó y publicó una proclama en 1597 justificando la invasión de Inglaterra cuyo fin - igual que en 1588 - era poner fin a las intervenciones inglesas en los asuntos de la Monarquía Hispánica (Lauer, 2019, p. 620).

En los años posteriores a la pérdida de la gran Armada, Alejandro Farnesio y otros ministros del rey continuaron sosteniendo las ventajas económicas y estratégicas que tendría para la guerra de Flandes invadir Inglaterra desde las costas flamencas - o al menos controlar alguno de sus puertos - contando para ello con una armada potente. Algunos de estos planes fueron elaborados por Joaquin Butgens, miembro del Almirantazgo ${ }^{11}$, Diego Brochero, almirante general del Océano ${ }^{12}$ o el coronel Guillermo Stanley ${ }^{13}$; incluso el archiduque Alberto envió su opinión sobre esta idea a instancias de Felipe II $^{14}$. Todos ellos tenían en común la necesidad, en primer lugar, de reconstruir la flota de Flandes. Este era un tema recurrente entre los miembros del consejo de Estado, los gobernadores de Flandes y aquellos que enviaban memoriales a la corte española. Sin embargo, establecían la táctica naval como un elemento para

9 Los documentos del tratado se pueden consultar en Bibliothèque Nationale de France (en adelante BNF), Departement des Manuscript. Cinq cents de Colbert 324. Traites entre la France et la Hollande (1596-1664).

Felipe II, además de negociar con Spínola, escribió al conde de Santa Gadea, que acaba de tomar el puerto de Brest en Francia, para que con sus barcos que fuese a apoderarse de un puerto en la entrada del canal de Inglaterra. AGS, Estado, 2224-1, f. 260, El Pardo, 11 de noviembre de 1597.

11 AGS, Estado, 614, f. 122 y sig. noviembre de 1597.

12 AGS, Estado, 615, f. 56, Ferrol, 29 de diciembre de 1598.

13 AGS, Estado, 2224-1, f. 240 a 242, Madrid, 1 de abril de 1597.

14 AGS, Estado, 613, f. 120, Bruselas, 3 de abril de 1597. El parecer del archiduque era contrario a emprender cualquier acción debido a la falta de hombres y fondos existente que solo le permitían hacer una guerra defensiva por tierra y tampoco tenía barcos ni puertos donde alojarlos. 
la lucha económica (Rodríguez, 2019, p. 224) o como un complemento de la estrategia militar terrestre, no como algo con entidad propia y, por tanto, la armada se presentaba supeditada a los recursos del ejército de tierra y sus estrategias (Riaño, 1999, cap. 5). Este sometimiento y la escasez de fondos hizo que Felipe II fuese postergando la puesta en marcha en Flandes de un proyecto sólido de construcción de barcos y puertos suficientes para estos, las iniciativas quedaron limitadas prácticamente a reformar de nuevo el Almirantazgo y a proponer su traslado a Calais en septiembre de 1596 por considerarlo más a propósito ${ }^{15}$ —idea que después se desechó por ser demasiado caro el acondicionamiento del puerto- - El consejo del Almirantazgo, por su parte, elaboró un proyecto para interrumpir el comercio en el Canal entre ingleses y holandeses que consistía en robar 50 filibotes holandeses y utilizarlos contra ellos dotándolos con 60 hombres cada uno; el coste anual se estableció en 500.000 escudos incluyendo municiones, aderezos, calafetaje y sustento de los soldados ${ }^{16}$; un precio inasumible para las finanzas del ejército de Flandes y muy caro con respecto a otras opciones ${ }^{17}$.

Por otro lado, en ese momento la crisis económica de la corona española ya había planteado serias dificultades al mantenimiento de la fuerza militar en los Países Bajos (Esteban, 2002b, p. 56). Durante los primeros años de la década de los noventa las victorias españolas en suelo francés ampliaron la línea de batalla que tenía que cubrir el ejército de Flandes. Los soldados eran claramente insuficientes para mantener todo el territorio y se precisaban más recursos para defender con éxito ambos frentes. Aunque se hizo un gran esfuerzo económico en plena crisis financiera — en el ejército de tierra los soldados habían pasado de los 30.000 en enero de $1596^{18}$ a algo más de 40.000 en octubre de $1597^{19}$ — no se había avanzado en la toma de una decisión relativa a los medios navales y al levantamiento de una flota significativa. De hecho, esto no ocurrió hasta que en 1603 Felipe III creó la Junta para la fábrica de navíos (Gasch-Tomás, Trápaga, Trindade, 2017, p. 188). Sobre la situación de la armada a la llegada del archiduque Alberto, este escribió en 1596 a Felipe II informándole que había muy pocos barcos útiles «que no pasan de 8 a 10 y los puertos son poco capaces y particularmente de navíos gruesos y galeras» ${ }^{20}$.

15 AGS, Estado, 611, f. 137, 22 de septiembre de 1596. Relación de siete cartas del archiduque.

16 El coste planteado es desmedido si se tiene en cuenta que la oferta de Spínola es de 300.000 escudos. En general, era bien conocido por la administración española que lo más rentable era tener una armada por asiento. Sobre este tema AGS, Estado, 612, f. 122. Bruselas, 16 de marzo de 1596, relación de los papeles dados por Esteban de Ibarra.

17 Federico Spínola estimó el gasto anual de cada galera en una cantidad similar, pero con la diferencia de que tenía previsto embarcar 250 remeros y 50 soldados en cada barco. AGR, Audience, 1464-2, sf, carta de Federico Spínola, circa 1595.

18 AGS, Estado, 611, f. 55, enero de 1596.

19 AGS, Estado, 614, f. 65. Arras, 23 de octubre de 1597.

20 AGS, Estado, 611. f. 222. Bruselas, 9 de diciembre de 1596. 
Este panorama alentaba la idea de involucrarse en proyectos navales diferentes, como por ejemplo el presentado por Federico Spínola, menos complejo de poner en marcha y que, según su planteamiento, hacía más efectivos 30.000 ducados invertidos en fuerzas navales que 300.000 gastados en un ejército terrestre. Este genovés era hermano menor del marqués Ambrosio Spínola, una de las principales figuras de la república genovesa y cabeza de la rama más rica y poderosa de la familia, los Spínola de San Luca (Rodríguez Villa, 1904, cap. 1; Retortillo, 2017, cap. 2).

Federico, nacido en Génova en 1571, era hijo de Felipe Spínola, marqués de Sexto y de Benafró, al que se le conocía como el patriarca por la inmensa fortuna que tenía. Desde los quince años destacó en las actividades bélicas (De Herrera, sf, f. 69v) y fue descrito por una de las esposas de sus oficiales como de esbelta figura y siempre sonriente (Corbett, 1900, p. 278). En 1591 viajó a Flandes pagándose él mismo todos los gastos de «servir con una pica» en el ejército ${ }^{21}$. Junto a las tropas del duque de Parma participó en la guerra contra los protestantes de Enrique de Navarra en las campañas de Bretaña. Asistió al lado de Alejandro Farnesio junto a nobles españoles como Martín de Leyva y Cabrera, príncipe de Asculi o Alfonso de Ávalos, marqués del Vasto e italianos como Marco Pio de Saboya, príncipe de Saxoli (Estrada, 1701, L. III, p. 329; Rizzo, 1998, p. 473). Especialmente destacada por los historiadores fue la participación de Spínola en el sitio de Rouen en febrero de 1592, donde le hirieron en la frente, dejándole el rostro marcado (Aranda, 1693, L. I, cap. IV, p. 22). La opinión general que se tenía de él entre el resto de soldados es que era osado, belicoso y bizarro, por lo que fue estimado por Farnesio que lo hizo uno de sus «hombres de opinión»» ${ }^{22}$.

A la muerte del duque de Parma en diciembre de 1592, Federico permaneció en el ejército de Flandes pero reorientó sus objetivos manteniendo su compromiso con la corona española ${ }^{23}$. Spínola tenía un amplio conocimiento sobre marina; había servido un breve periodo de tiempo en las galeras del Mediterráneo (Casoni, 1691, p. 16; Fernández Duro, 1973, tomo III, p. 207) y era propietario - junto a su hermano Ambrosio - de cuatro galeras heredadas de su tío Agustín Spínola con las que servía

21 En el documento de confirmación del título de marqués de los Balbases, otorgado por Felipe IV a Ambrosio Spínola, el rey refiere los servicios de Federico como un motivo más otorgarle el título. Allí indica que sirvió 8 años en el ejército de Flandes y 4 como gobernador de las galeras que se enviaron a esos estados «siendo el primero que con ellas navegó». Archivo de la Casa Ducal de Alburquerque (en adelante ACDA), Balbases, 92-2.

22 Los sucesos de Flandes y Francia del tiempo de Alejandro Farnese por el capitán Alonso Vázquez, sargento mayor de la milicia de Jaén y su distrito. Terminado en Jaén el 1 de mayo de 1614. BNM, MSS. 2767, p. 697.

23 «Deseo mostrar a VM por servirle en todo lo que mis fuerzas permitieren el celo y honrado fin que me ha movido y mueve a empeñarme con la honra, vida y hacienda», AGR, Audience, 1464-2, sf, propuesta de Federico Spínola, circa 1595. 
a la corona española en la escuadra de Génova ${ }^{24}$. Por ello, en marzo de 1593 presentó a Esteban de Ibarra, que estaba al frente de la Secretaría de Estado y Guerra, un proyecto extremadamente novedoso de estrategia naval en la lucha contra los rebeldes ${ }^{25}$; dado el interés suscitado en Bruselas, al año siguiente el gobernador archiduque Ernesto le envió a la corte para que plantease el negocio personalmente a Felipe II. A principios de 1595, Federico llegó a Madrid y desde el consejo de Estado se iniciaron entonces conversaciones con él de cara a concretar las características del proyecto ${ }^{26}$. Tras el fallecimiento de Ernesto de Austria y el envío a Flandes de su hermano, el archiduque Alberto, en 1596 se paralizó el asunto y Federico fue enviado a su casa en Génova. A principios de 1597, Juan de Idiáquez, secretario de los consejos de Estado y Guerra, que había sido embajador en Génova y conocía a la familia Spínola, le mandó llamar para seguir con las conferencias; en la Pascua de 1598 se tomaron las primeras resoluciones prácticas tras lo que Spínola viajó de nuevo a Flandes para poner en marcha la empresa ${ }^{27}$.

En el primer proyecto de Federico — presentado en 1593 y negociado hasta 1596 - la idea principal era ayudar a defender las costas de las provincias leales y reducir aquellos estados a la obediencia de la corona española ${ }^{28}$. Para ello, su intención era interrumpir o molestar el tráfico de los rebeldes, transportar las tropas reales, cuidar de su comunicación y socorrer los lugares amenazados por los rebeldes (Fernandez Duro, 1973, t. III, p. 207):

He propuesto en hacer una armada de navíos en forma de galeras para guarda y conservación de aquellos estados [...] para dar molestia y daños a los enemigos $[\ldots]$ por la falta de aparejo que hasta aquí se ha tenido en aquellos estados en las cosas de la mar $[\ldots]$ y lo mucho que los enemigos han prevalecido ${ }^{29}$.

En el memorándum que Spínola envió poco antes de su muerte explicaba que, cuando llevaba dos años en Flandes, se dio cuenta de que ganar la guerra contra los rebeldes por tierra era muy dificultoso. Por lo que él había podido ver ${ }^{30}$, cuando el

24 AGS, Estado, 1437, f. 163, 1615. Carta de Agustín Spínola, hijo de Ambrosio, sobre sus galeras: «son 4 galeras con las que su padre y su tío sirvieron en la escuadra de Génova desde hace 40 años» que ellos habían heredado en 1593 de su tío Agustín. Sobre esta herencia: AGS, Galeras, 4, f. 503, carta de poder de Federico Spínola, (ver también Carpentier, Prioriti, 2015, p. 93).

25 AGR, Audience, 1464-2. Memorie del signor marcheses per il segnor Federico suo fratello, circa 1593.

26 AGR, Audience, 1464-3, sf. 12 de abril de 1595.

27 AGS, Estado, 621, f. 54. Memorando de Federico Spínola, circa 1603.

28 AGS, Estado, 2224-1, f. 180. Madrid, 4 de mayo de 1597.

29 AGR, Audience, 1464-2, sf, Memorando de Federico Spínola, circa 1593.

30 Casoni (1691, libro I), narra sobre la vida de Federico Spínola que no había ido a Flandes para tener una vida ociosa o participar en cazas, juegos u otros pasatiempos, si no que su fin era convertirse en el «perfecto capitán» y que para ello estudiaba continuamente sobre las Provincias, la cualidad y costumbre de las gentes, la documentación militar de hombres de experiencia. Especialmente su 
enemigo sitiaba una plaza - cosa que hacía en un solo día - el ejército de Flandes tardaba muchos días en llegar hasta allí, dando tiempo al enemigo a fortificar el terreno, complicando enormemente el retomarla ${ }^{31}$. Evitar el sitio de las plazas situadas en territorios leales era prácticamente imposible porque habría que fortificarlas todas y tener un ejército grande y muy bien provisto; además, en caso de necesidad de más soldados, los socorros venían de España o de otras partes mientras que los de las islas los tenían mucho más cerca ${ }^{32}$.

Por ello, su propuesta de crear una armada para someter a los rebeldes tenía una doble vertiente. Spínola había estudiado el sitio, bancos, canales, puertos y puestos de aquella costa, su forma de gobierno y sustento de aquellas islas y visitado personalmente todo lo que le fue posible ${ }^{33}$. En consecuencia, planteaba que, en el avance militar, las galeras podían atacar directamente a los rebeldes pues sería muy fácil enviar dos o tres mil soldados a ofender algún fuerte; en esto se tardaría un solo día y las fuerzas que ellos tenían en los presidios no llegarían a tiempo de socorrerlos; también podían transportar esas tropas a algún puerto de mar en Holanda o Zelanda donde él había podido comprobar que muchos no estaban amurallados. Estas mismas galeras permitirían socorrer a los soldados mientras se construía una fortificación. En defensa, las galeras podían llevar hombres rápidamente a las plazas que sitiasen los rebeldes evitando que estos se hiciesen fuertes dentro. Además, proponía un punto de ataque: la isla de Casante; Spínola planteaba la construcción allí de dos fuertes, y con tres o cuatro galeras en cada uno se controlaría el canal de Vlesinga que era el principal de Zelanda ${ }^{34}$.

Igualmente, debido a la información directa que Federico había reunido sobre los Países Bajos, creía saber qué tipo de actividades de carácter comercial podían ayudar a terminar con la rebelión de Holanda y Zelanda. En su opinión, dado que estas provincias tenían una economía basada en el comercio marítimo, igual que Génova, cortar su fuente de ingresos debilitaría mortalmente su economía y, por tanto, su causa. Federico planteaba que la mayor parte de las provincias rebeldes eran praderías en las que no se recogía trigo suficiente para hacer pan que durase ni seis meses, «ni tienen aceite, ni sal, ni vino ni otras cosas necesarias al uso humano» por lo que no podían vivir sin el contacto con países extranjeros ${ }^{35}$. Para ello, la idea dise-

mayor esfuerzo fue el de seguir el ejemplo de Alejandro Farnesio en su desempeño militar.

Aunque después de la partida de Flandes de Ranuccio Farnesio no se incorporó de forma oficial en ningún Tercio, su relación con Gastón Spínola — pariente suyo y maestro de campo general entre 1592 y 1594 - le abrió muchas puertas. De hecho, el sargento mayor del Tercio de Gastón Spínola, Pompeo Giustiniano, pasaría a su servicio primero y al de Ambrosio Spínola después (Retortillo, 2018, p. 192). Sobre los italianos en el ejército de Flandes, véase Bertini (2018). AGR, Audience, 1464-2, sf. Memorando de Federico Spínola, circa 1593. AGS, Estado, 621, f. 54. Memorando de Federico Spínola, circa 1603. AGR, Audience, 1464-2, sf. Memorando de Federico Spínola, circa 1593. AGR, Audience, 1464-2, sf, Memorando de Federico Spínola, circa 1593. 
ñada consistía en hostigar el tráfico marítimo holandés, evitando de paso los ataques ingleses a las poblaciones costeras de las provincias leales. Puesto que lo que los mantenía ricos y poderosos eran la navegación y la pesquería estos debían ser el objetivo principal ${ }^{36}$. Detallaba también los beneficios que se podrían conseguir creando esta armada; por un lado, se podrían anular las relaciones entre rebeldes e Inglaterra porque la ausencia de comercio y el dinero que este generaba impediría comprar trigo inglés y, además, no tendrían para pagar soldados ingleses; por otro lado, el negocio de pescado — esencialmente arenques - era del que más provecho obtenían los rebeldes, puesto que por ley todos los habitantes de las provincias rebeldes tenían obligación de consumirlo dos o tres días por semana y la mayor parte de este pescado venía en salazón de la zona más septentrional.

La novedad del proyecto estaba en usar galeras, ligeramente modificadas, en vez de los galeones que mayoritariamente había encargado Felipe II para rehacer su armada después de 1588. El uso de las galeras del Mediterráneo en el mar del Norte ha sido visto por parte de la historiografía anglosajona como una osadía, al querer hacer frente con estas naves a la potencia de los galeones holandeses e ingleses (Motley, 1868, vol. 4, p. 113; Warner, 1963, p. 38; Francis, 1981, p. 177). Motley - considerado bien documentado, pero tendencioso por sus apreciaciones (Sanz Camañes, 2004, p. 960; Ebben, 1998, p. 82) — describió las galeras de Spínola como:

\begin{abstract}
una producción tan torpe y ampulosa como se podría esperar de la persistencia humana. Expuesta, plana y frágil, ancha en la cintura, ancha en la proa y en la popa, torpe en las maniobras, indefensa en condiciones de mal tiempo, lenta en la navegación. A pesar de tener la única ventaja de poder arrastrarse sobre un mar suave cuando los barcos mejores y más rápidos se paralizan por la calma absoluta, la galera no es rival para la galera holandesa, ya sea a corta distancia o con brisa.
\end{abstract}

Para otros autores, sin embargo, Federico hizo una demostración extrema de sus habilidades sacando el máximo provecho de este tipo de barcos en el mar del Norte donde, por su poco calado, podía hacer mejor uso que de los galeones. Los puertos poco profundos y las vías navegables interiores propios de las provincias del norte, hasta ahora, habían demostrado ser ineficaces para barcos más grandes (Gray, 1978, p. 71-83; Maland,1980, p. 28; Graham, 1972, p. 240; Fernández-Armesto, 1988, p. 127). Mientras que una galera podía navegar con 5 o 6 pies de agua, los barcos holandeses necesitaban al menos el doble de profundidad, lo que les dificultaba el aproximarse a la costa para embarcar y desembarcar hombres y mercancías necesitando puertos de aguas profundas muy escasos en esas costas. Estos barcos, más grandes y cargados con más cañones, permitían a los marineros de las provincias viajar al 
Nuevo Mundo, pero eran poco maniobrables en las costas de las Provincias Unidas y tenían un grave inconveniente como explicaba Spínola:

al ser de vela con calma no se pueden menear y con viento no pueden proejar [navegar contra el viento] como hacen estos con los remos por tener vela a la latina. Además, en caso de batalla con artillería los daños que sufriría un navío eran mayores que los de una galera por tener mayor cuerpo ${ }^{37}$.

Por esto, el proyecto de Federico planteaba la construcción de unos barcos en forma de galeras con vela latina, algo diferentes — más cortas que las normales - aunque de la misma traza y proporción. Esta construcción naval ya se había probado con éxito en tiempos de Alejandro Farnesio, sobreviviendo sin dificultad en 1588 a la misma tormenta que había desbaratado la armada del duque de Medina Sidonia ${ }^{38}$. Los holandeses, una vez probada la eficacia de la galera, también construyeron algunos de estos barcos como los que atacaron el puerto de Amberes en diciembre de $1600^{39}$.

Desde el punto de vista práctico, el ofrecimiento consistía técnicamente en un asiento de galeras similar al que se utilizaba en la gestión de la armada española en el Mediterráneo, y que utilizaban también la mayor parte de las flotas como la de Toscana, Estado Pontificio, Piamonte o Francia (Lo Basso, 2007, p. 390). En este tipo de acuerdo (appalto), el asentista obtenía la administración y gestión de los barcos propiedad del rey junto al mando militar de los mismos. En ella, mediante el convenio establecido entre el rey de España y un particular, el patrón se comprometía, durante un tiempo determinado, a poner en servicio un número de barcos — armados, pertrechados y con su correspondiente tripulación - por una cantidad de dinero u otras contraprestaciones.

En relación con lo económico, la oferta de Spínola era muy ventajosa. En el detallado presupuesto que envió en 1595 calculaba que construir diez galeras nuevas en Flandes costaría 300.000 escudos y se tardaría 30 días en finalizarlas. El presupuesto anual de las galeras necesarias para su proyecto — 11.000 escudos cada una - era algo más de lo que costaban las del Mediterráneo, que Federico justificaba indicando que con el frío se daban mayores raciones a los marineros y remeros, a los que no se podía licenciar nunca porque eran difíciles de conseguir y en el norte debían estar siempre disponibles para el servicio ${ }^{40}$. Esteban de Ibarra, con el que Federico negoció en Flandes en 1593-1594 y en Madrid en 1597-1598, consideraba que la

37 AGR, Audience, 1464-2, sf. Memorando de Federico Spínola, circa 1593.

38 AGS, Estado, 2224-1, f. 180, Madrid, 4 de mayo de 1597.

39 CODOIN, vol. LX, 1875, p. 258. También, AGS, Estado, 617, f. 126, Bruselas, 10 de diciembre de 1600 .

40 AGR, Audience, 1464-2, sf, Propuesta de Federico Spínola, circa 1595. 
cantidad presupuestada «ni es grande en comparación de lo que importa este negocio ni desacomodada para el estado que se pretende tiene la hacienda de Su Majestad» y que una empresa de esta envergadura no podía llevarse a cabo con cinco bucos [barquitas] sobre todo teniendo en cuenta que se «aventura mucho más de eso con menos fundamento» ${ }^{41}$.

El recurso a las empresas financieras privadas fue empleado en numerosas ocasiones por la corona debido a que en la administración eran frecuentes los desacuerdos entre la previsión del gasto y la realidad del mismo (Esteban, 2002a, p. 70). Por ello, en las conversaciones con Spínola se acordaron varios puntos relacionados con la gestión financiera del proyecto; sus peticiones eran poco habituales en este tipo de conciertos debido a que no tenía ningún deseo de enriquecerse con este proyecto, según él indicó ${ }^{42}$. Solicitó a Felipe II que los pagos se le realizasen en España en consignaciones «sobre imposiciones firmes a mi elección» que se cobrarían cada cuatro meses a cambio de no cobrar ningún interés por el dinero adelantado el primer año para poner las naves en marcha — que estimó en 300.000 escudos—; también pidió que para la administración de este dinero que iba a adelantar él pudiese nombrar al contador, veedor y pagador que los gestionasen ${ }^{43}$. Para Felipe II, el planteamiento realizado por Federico aportaba el beneficio adicional del ahorro con respecto a otras opciones puesto que se había comprometido a financiar personalmente y sin intereses los gastos de la flota ${ }^{44}$; en el Mediterráneo, el armador anticipaba el dinero necesario cobrando intereses de entre el 12 y el 14 \% sobre lo invertido (Lo Basso, 2007, p. 401).

Aunque lo habitual en un caso de asiento era que los barcos estuviesen integrados en una escuadra mayor, en este caso, Spínola negoció que no se incluyesen estas galeras bajo la administración del Almirantazgo de Flandes por considerarlo inoperante y que, por su compleja organización, sería el consejo el que tendría todo el poder sobre el comandante de los barcos, los marineros y cualquier actividad de los mismos; de hecho, su funcionamiento era tan caótico que aunque entre las funciones de este estaba el sostener a su costa 24 navíos «armados en guerra» lo cierto es que

41 AGS, Estado, 2224-1, f. 178, Madrid 4 de mayo de 1597, sumario de Esteban de Ibarra de los papeles presentados por Federico Spínola. Mismo documento en AGR, Audience, 1464-2, sf, Madrid, 4 de mayo de 1597.

42 Estas peticiones manifiestan el conocimiento que Federico Spínola tenía de la mala situación económica de la corona y de qué tenía que solicitar al rey para poder recuperar con cierta seguridad el dinero prestado. Su padre, sus tíos, sus abuelos, su hermano y él mismo tenían juros en diversos puntos de la península y sabía cuáles de ellos eran los que mejores rendimientos producían. Pero, aun así, de todo el dinero que Federico invirtió, su hermano Ambrosio no consiguió recuperar más que una mínima parte y varias décadas después. AGR, Secretairerie de État et Guerre, 128, f. 21 26.

43 AGR, Audience, 1464-2, sf, Propuesta de Federico Spínola, circa 1595.

44 De hecho, en las últimas negociaciones con Felipe II en 1597 Spínola ofrece servir gratis con los barcos el primer año. AGR, Audience, 1464-2, sf, Madrid, 4 de mayo de 1597. 
cuando el archiduque Alberto llegó a Flandes en 1596 había allí solo unos pocos barcos repartidos entre Calais y Dunquerque ${ }^{45}$ (Fernandez Duro, 1973, p. 230).

Por otro lado, seguramente Federico era consciente de los problemas internos de corrupción existente entre los oficiales del almirantazgo y las dificultades con el nombramiento del almirante, de lo que Esteban de Ibarra - con quien Federico tenía estrecha relación - ya había dado cuenta a Felipe II $^{46}$; por ello en las capitulaciones que Spínola firmó con la corona española se le concedió el título de general de estas galeras y él nombró a Aurelio Spínola como su teniente general ${ }^{47}$.

\section{Las galeras de Spínola y la geoestrategia de la Monarquía Hispánica en el canal de la Mancha}

El proyecto redactado en 1593, que se estuvo trabajando hasta 1596, tenía como objetivo terminar la guerra con Holanda y Zelanda; pero cuando se retomó en 1597 evolucionó en cuanto a sus objetivos hasta crear una propuesta diferente. Las circunstancias políticas que se daban en torno al Canal de la Mancha en ese momento hicieron que alguna de las sugerencias anteriores de Spínola —usar sus galeras para llevar soldados a suelo inglés - pasasen a un primer plano relegando otros aspectos más comerciales del plan inicial. Desde finales de 1596 la corona española había decidido que la mejor estrategia para limitar los ataques de los barcos ingleses era pasar el estrecho y ofender a Isabel en su terreno ${ }^{48}$. La decisión venía favorecida por el hecho de que esta carecía de un ejército permanente que vigilase las costas y sus puertos estaban poco fortificados lo que hacía vulnerable a la isla (Tenace, 2003, p. 857). Otro elemento que contribuía a ello era que tanto los católicos ingleses como los enviados papales presionaban a Felipe II para que destronase a la reina protestante (Hume, 1901, p. 510). Esto, unido a los graves ataques que se sufrían en todos los mares por parte de la flota inglesa, animó al rey a poner en marcha nuevos proyectos navales contra Inglaterra, aunque sin excluir los contactos diplomáticos de bajo nivel tendentes a crear un acercamiento por si se daban las condiciones precisas para fina-

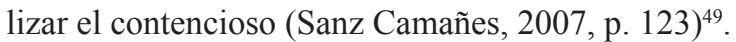

A pesar de ello, los miembros de la administración española en Bruselas manifestaron un alto grado de resiliencia con respecto a esta idea; el archiduque Alberto advirtió en diciembre de 1596 que desde Flandes no se podría apoyar ninguna

$45 \quad$ AGS, Estado, 2224-1, f. 176. San Lorenzo, 8 de junio de 1597.

46 AGS, Estado, 612, f. 122, Bruselas 16 de marzo de 1596, papeles enviados por Esteban de Ibarra. Véase también, Hortal Muñoz, 2008.

47 AGS, Estado, 2224-2, f. 297. San Lorenzo, 26 de junio de 1602.

48 AGS, Estado, 2223, f. 186. Madrid, 31 de diciembre de 1596.

49 AGS, Estado, 615, f. 42. Bruselas, 5 de diciembre de 1598. Carta del gobernador interino Andrea de Austria en la materia de paz con los ingleses. 
empresa en Inglaterra porque no tenía gente suficiente ni los barcos necesarios, ya que estaba luchando simultáneamente con los franceses en Artois y los rebeldes en Brabante $^{50}$. Precisamente esta actitud, basada en la certeza de que no se podía contar con los recursos españoles en Flandes, facilitó el éxito de Esteban de Ibarra cuando volvió a sacar a la luz el plan de Spínola paralizado desde hacía meses ${ }^{51}$. Ibarra, llegado poco antes a la corte desde Bruselas, impulsó el proyecto de Federico que volvió a adquirir relevancia; Juan de Idiáquez ${ }^{52}$, realizó en mayo de 1597 un resumen de todos los papeles que Federico había enviado a Madrid hasta la fecha; a ellos añadió de su puño y letra que, para cualquier cosa que se quisiese emprender contra Inglaterra, las galeras serían de mucho provecho ${ }^{53} \mathrm{y}$, como añadía Ibarra, con ellas en Flandes «los ingleses tendrían mucho cuidado de venir a infectar las aguas de estos reinos» ${ }^{54}$. Tras esta recapitulación del plan, la idea aportada por Spínola — inspirada por Ibarra e Idiáquez - se adaptó fácilmente al momento estratégico en el que se encontraba la Monarquía Hispánica. Federico, de nuevo en la corte, retomó las conversaciones sobre su empresa, pero el plan inicial de limitar la navegación en el Canal de la Mancha luchando contra los rebeldes atacando y defendiendo las costas de Flandes, se transformó en un proyecto para poner un pie en algún puerto de Inglaterra.

\begin{abstract}
Juzgando yo el estado en que veía las cosas, la necesidad forzosa que había de allanar las cosas de Inglaterra y de las tres armadas que Su Majestad había ya juntado [contra ella...] Su Majestad debía de tener intención de ocupar un puerto en Inglaterra [...] y considerando que estante las cosas en el estado que estaban cuan dificultosamente podía tener buen suceso cualquier empresa que se tentase contra Inglaterra con navíos de alto borde ${ }^{55}$.
\end{abstract}

Spínola solicitó que con las galeras se le diesen 5.000 soldados y 1.000 caballos; con ellos podría ocupar un puerto en la isla, fortificarlo y defenderlo de forma que «no le forzaría toda Inglaterra» ${ }^{56}$. Este nuevo planteamiento terminó por favorecer el futuro de su empresa que se aprobó definitivamente en el verano de 1598. La

50 AGS, Estado, 611, f. 222, Bruselas, 9 de diciembre de 1596, carta del archiduque Alberto al rey.

51 AGS, Estado, 2224-1 minutas de cartas f. 176, San Lorenzo 8 de junio de 1597. Carta del rey al archiduque Alberto: «de acá llevasteis entendido lo que proponía Federico Spínola y [...] se ha tornado a platicar de este negocio».

52 Esteban de Ibarra era hechura de Juan de Idiáquez y, por tanto, la vida política del primero estaba estrechamente vinculada al segundo (Hortal Muñoz, 2008, p. 92); ambos fueron siempre los valedores de los hermanos Spínola en la Corte española.

53 AGS, Estado, 2224-1, f. 178, Madrid, 4 de mayo de 1597. Sumario de Esteban de Ibarra de los papeles presentados por Federico Spínola,

54 AGR, Audience, 1464-3, sf, Madrid, 4 de mayo de 1597. Sumario de los papeles que ha presentado Federico Spínola.

$55 \quad$ Ibid

56 AGS, Estado, 621, f. 54. Memorial de Federico Spínola visto en el consejo de Estado de 5 de febrero de 1602 . 
muerte de Felipe II pocas semanas después dejó sin cerrar la firma de los acuerdos finales y puso en manos de su hijo la continuidad de la política contra Inglaterra. El consejo de Estado y el nuevo rey suponían que, tras la firma de la Paz de Vervins con Francia, Isabel no desearía hacer frente ella sola a los gastos de hombres y dinero que significaban el apoyo a las Provincias Unidas (Wernham, 1994, p. 4). Por tanto, la intención de Felipe III a finales de 1598 era la de hacerse con algún puerto en Inglaterra para obligar a su reina a aceptar de mejor grado algún tipo de acuerdo que terminase con el conflicto iniciado dos décadas antes. Para ello, a la vez que en diciembre de 1598 firmaba las capitulaciones con Federico ${ }^{57}$, inició contactos diplomáticos para conocer las peticiones inglesas de cara a abrir una negociación (Lonchay, Cuvelier, 1923, doc. 15$)^{58}$.

Los cambios en la política exterior española sucedieron cuando Federico se encontraba ya en Bruselas. Aunque no se había estampado la firma del acuerdo, Spínola viajó a Bruselas ese mismo verano para hacer los preparativos necesarios para poder llevar a cabo su proyecto en 1599. Allí hizo varias provisiones de dinero para la recluta de soldados y compra de los bastimentos necesarios sin los cuales el proyecto se podría retrasar un año. Entre los preparativos se encontraba el reconocimiento de los puntos desembarco en Inglaterra, por lo que envió un agente, Hortensio Spínola, a examinar los puertos ingleses; pero este fue descubierto, detenido e interrogado en la cárcel de Newgate en Londres; más tarde fue intercambiado por un confidente inglés, Richard Hawkins, preso en Madrid ${ }^{59}$. En junio de 1599, Federico se dirigió a Santander para recoger seis galeras procedentes de la desmovilización de la armada de Bretaña establecida en Port Blavet y se dirigió hacia Dunquerque, donde se le había indicado que debía establecer la base de su armada (Gelabert, 2007, p. 69). En Flandes debería construir, con una nueva traza, cuatro o cinco galeras el primer año, con armadores genoveses, para poder sumar el número mínimo de diez que había solicitado en su plan.

Con un nuevo rey en España y un nuevo señor en los Países Bajos sus objetivos variaron poco. Felipe III se limitó a recordar al archiduque que tenía obligación de ayudar a Spínola, porque el proyecto era para su propio beneficio, aunque le dio la opción de avisarle para detenerlo si las conversaciones con Londres avanzaban lo suficiente. De momento, se pidió a Federico que se mantuviese en el Canal cortando el tráfico a los holandeses y zelandeses hasta ver que efecto tenían los nuevos contactos diplomáticos. Sin embargo, las peticiones iniciales inglesas fueron tan desproporcionadas que Felipe III estuvo a punto de no continuar con ellas si no se hubiese señala-

57 AGS, Estado, 2224-1, f. 16. Aranjuez, 8 de diciembre de 1598.

58 También AGS, Estado, 615, f. 42, Bruselas, 5 de diciembre de 1598. Carta del gobernador interino Andrea de Austria al rey.

59

Historical Manuscripts Commission (1904, p. 245). 
do ya el puerto de Boulogne para reunir a los diputados ${ }^{60}$. Poco después se supo que los ingleses no tenían intención de incluir ninguna limitación de sus relaciones con las Provincias Unidas en el acuerdo lo que terminó por enfriar las negociaciones ${ }^{61}$. Por lo que en febrero de 1601 desde el consejo de Estado se instó a Federico Spínola a poner práctica su proyecto de invadir Inglaterra ${ }^{62}$.

Debido a las redes de agentes y espías que funcionaban en las cortes europeas, todos sus movimientos eran conocidos en Londres en pocos días, creando un ambiente de permanente sospecha (Sanz Camañes, 2007, pp. 116-117). Los ingleses habían conseguido establecer un espía entre los capitanes de barco en Flandes, el capitán Smith, que descontento con su situación en Bruselas había aceptado informarles de todos los movimientos navales de los barcos españoles ${ }^{63}$. Además, los embajadores venecianos enviaron relaciones desde España y Francia de todos los pasos que iba dando el proyecto de Federico (Brown, 1897, pp. 353-360, no 764; Barozzi e Berchet, 1856, p. 117). Los ingleses estaban preocupados por la posible llegada a sus costas de armadas españolas, pero en el verano de 1599 lo estaban especialmente por lo que se ha llamado «la armada invisible». Desde junio de ese año habían ido llegando a Londres diversos avisos informando que el Adelantado estaba formando una gran flota de 170 barcos y 30.000 hombres, ayudados por barcos daneses y soldados del rey de Escocia para invadir Inglaterra probablemente atacando el estuario del Támesis o en Kent; esto provocó una reacción inmediata en Londres que ordenó reforzar las defensas de Plymouth, la Isla de Wight y Portsmouth, levantar un ejército de 25.000 soldados y preparar una gran flota para tratar de hundir la mayor cantidad posible de barcos españoles en el Canal. Desde La Rochelle, a primeros de agosto, incluso llegaron noticias del avistamiento de esta flota española que resultaron falsas puesto que no existía tal proyecto (Wernham, 1994, pp. 263-283; Corbett, 1900, chapter XI, pp. 253-290).

Sin embargo, «la armada invisible» favoreció el paso de Spínola por la costa bretona, ya que al ser detectados por los ingleses estos pensaron que era solo la avanzada de la gran armada y no fueron atacados en espera de una cantidad mayor de barcos. En Londres también estaban prevenidos en relación con las actividades del genovés y habían seguido con detalle los pormenores de su viaje desde Santander. Cuando llegaron a Inglaterra las noticias de la aparición en las costas bretonas de las seis galeras de Spínola se renovaron las dudas sobre si detrás de él llegaría el resto de la armada española procedente de Ferrol. Aun así, en cada uno de los puertos en los que recaló la escuadra había informadores que enviaron sus noticias a Londres

60 AGS, Estado, 2224-2, f. 4, Bruselas, 29 de febrero de 1600, minuta de carta de Felipe III a Baltasar Zúñiga.

61 AGS, Estado, 2023, f. 3, 19 de diciembre de 1600.

62 AGS, Estado, 2023, f. 36, Oficio del consejo de Estado 3 de julio de 1601.

63 Historical Manuscripts Commission (1904, p. 6-8). Captain Robert Ellyott to Sir Robert Cecil, 13 de enero de 1599. 
por lo que conocían que tras partir de Santander recalaron en Conquet - cerca de Brest—-, después en L'Havre, y llegaron a Dunquerque (Graham, 1972, p. 254) y unos días después informaron que:

El rumor de que la flota española estaba frente a Inglaterra ha desaparecido; solo algunas galeras de Federico Spínola han pasado por Dunquerque. Sin embargo, la reina mantendrá la provisión para la guerra durante todo este mes, después de lo cual no hay más motivo de alarma debido a la naturaleza tormentosa de la temporada (Brown, 1897, p. 377).

\section{Conclusiones}

En general, Inglaterra dedicó mucho más interés a las acciones de Federico Spínola en el Canal de la Mancha del que se hizo en la Península Ibérica, seguramente a causa del miedo que les producía un posible ataque directo de sus galeras. De hecho, una victoria sobre los barcos de Spínola se consideraba una acción para la posteridad, y se exageraba y difundía en consecuencia (Dunthorne, 2013). Por ejemplo, en octubre de 1602 el almirante inglés Robert Mansel se jactaba ante lord Effigham del hundimiento de dos de las seis galeras de Federico y de la destrucción de las otras cuatro, cuando solo se habían perdido dos de ellas y el resto consiguió llegar a tierra sin mayores problemas. Posteriormente llegaron a Londres nuevas noticias refiriendo que las pérdidas de la flota española no eran de consideración; el disgusto de la reina Isabel por el desengaño sufrido fue tal que el almirante de la armada inglesa no osó aparecer delante de ella por un tiempo ${ }^{64}$.

La figura de Spínola ha sido muy valorada por los británicos, que lo han llegado a considerar como una de las figuras más brillantes del final de la guerra con Inglaterra y han definido su proyecto como una de las características más llamativas y descuidadas de la historia marítima española (Corbett, 1900, p. 278). En opinión de Graham (1972, p. 238), Federico demostró en 1599 cómo podría lograrse un uso magistral de ese buque de guerra anticuado. Para otros autores, Spínola ha sido considerado un pirata o corsario (Motley, 1868, p. 94). Esta idea errónea se debería a que el corso desde Dunquerque fue apoyado y favorecido por Felipe II como una forma de defender los intereses políticos y económicos en el norte (Sanz Camañes, 2012, p. 203; Otero Lana 2005, p. 116; Villiers, 2000, p. 91), a que Spínola atracó sus barcos en ese puerto en primer lugar — después se trasladó a La Exclusa (Sluis) — y a que Federico no dependía del Almirantazgo como el resto de embarcaciones.

64 AGS, Estado, 621, f. 46. Oficio del consejo de Estado de 14 de diciembre de 1602. Las dos versiones de la batalla de Goodwinds Sand se pueden leer en Jurien de la Gravière (1891, p. 28). 
Tras su llegada a Flandes, este se mantuvo navegando por el Canal atacando a los barcos holandeses a la espera de la evolución de las negociaciones con Londres. El éxito de las acciones por mar de las galeras de Spínola fue fulminante. Con sus barcos hizo mucho daño a la piratería holandesa en el Canal (Klingenstein, 1910, p. 124) y adquirió una notoriedad y una fama sobresaliente (Fernández Duro, 1972, tomo III, p. 214; Gray, 1978, p. 71; Gelabert, 2009, p. 1010). Con esta actividad capturó poco después de su llegada más de cuarenta barcones de pescadores holandeses (Roco de Campofrío, 1973, p. 264). Su armada bloqueó el tráfico marítimo en el Canal afectando al comercio de Inglaterra y las Provincias Unidas. Pero también Francia se vio afectada por las actividades militares de los barcos de Spínola y en octubre de 1600 Enrique IV escribió a su embajador en la corte española para que informase a Felipe III de la gravedad de las repercusiones económicas de lo que estaba sucediendo en el Canal con los barcos de Spínola (Gelabert, 2007, p. 69). Diez meses después de la llegada de Federico a La Exclusa, la archiduquesa Isabel informaba al duque de Lerma de la noticia de que los rebeldes de Holanda y Zelanda querían atacar ese puerto «para quemar las galeras porque les dan mucha pesadumbre» (Rodríguez Villa, 1906, p. 278).

La importancia de los ataques de Spínola influyó de forma relevante en la decisión de Mauricio de Nassau de atacar Ostende en 1601 (Barado, 1889, p. 18). Pero, además, durante el sitio, estorbó la armada holandesa que apoyaba a los asediados impidiendo el abastecimiento de la ciudad: «Federico con cuatro galeras suyas salteaba por momentos las barcas [rebeldes] y se las quitaba echando muchas a fondo con la artillería» (Novoa, 1875, vol. LX, p. 157). Además, infringió mucho daño en el mercado de las provincias y mantuvo en perpetuo pánico a la gente del mar de esas regiones que se disponían a extender la escala de sus operaciones después del éxito de los asaltos de almirante Van der Does a A Coruña y Canarias en 1599 (Motley, 1868, chap. XL, p. 114). Esto provocó que desde poco después de la llegada de Federico y sus galeras atacando a las flotillas de pesca, los convoyes de comercio y los puertos, el gobierno rebelde tuvo que hacer un gasto adicional significativo para escoltar sus barcos comerciales y reforzar sus puertos restando recursos en la guerra contra el rey de España.

La falta de apoyo desde Flandes a la empresa de Federico de invadir Inglaterra, decidida por Felipe III en 1600, fue una constante. El archiduque Alberto, partidario de la paz con Inglaterra, utilizó todos sus recursos en fortalecer su ejército terrestre, aunque esto no le impidió clamar por la presencia de una armada española en el Canal. La apropiación en varias campañas por parte de Alberto del dinero, armas, municiones y vituallas que Spínola iba reuniendo en Bruselas retrasó la puesta en marcha definitiva del plan inglés. Por ejemplo, en 1599 Federico reclamó el dinero que había dejado en Bruselas para pagar el sueldo a los 4.000 soldados que tenía 
pensado reclutar y que el archiduque había requisado. En 1601 Alberto se quedó con los soldados reclutados por Spínola porque Federico enfermó y no pudo poner en marcha el plan en esa campaña y en 1602 volvió a ocurrir lo mismo. De hecho, Spínola escribió en todas esas ocasiones a Felipe III informándole de las dificultades que tenía con la forma de actuar del archiduque. El rey escribió en términos muy serios a Alberto y pidió al embajador Baltasar Zúñiga que siguiese muy de cerca este asunto «y al dicho Federico tened siempre tan satisfecho como yo lo estoy de su persona y buen proceder» ${ }^{65}$.

La empresa terminó por desecharse definitivamente en 1603 cuando a la muerte de la reina Isabel, el 24 de marzo, le siguió la del propio Federico dos meses más tarde, el 26 de mayo. Este falleció en un enfrentamiento naval con barcos holandeses, en el que recibió un cañonazo en el brazo derecho, con el que sujetaba la espada, y la guarnición de la espada le dio en el rostro y la cabeza «tan crudo golpe que se la rompió y en breves horas rindió el espíritu» (Novoa, 1875, t. LX, p. 157; van Bruyssel, 1864, p. 149).

Después de Spínola, el espectro de la galera ya no atormentaría más a los responsables de defender a Inglaterra de la invasión (Wernham, 1994, p. 401). Por otro lado, en esas fechas el conflicto con los rebeldes pasaba por un delicado momento para los tercios españoles. Tanto el archiduque Alberto como Felipe III estaban más preocupados por la mala evolución del sitio de Ostende — que duraba ya dos añosy por la pérdida de reputación que supondría para la corona y para el ejército de Flandes levantar el asedio; especialmente cuando desde 1600 llevaban contabilizadas más derrotas que victorias contra los rebeldes. Además, el nuevo rey inglés, Jacobo I Estuardo, no estaba interesado en continuar el conflicto con la corona española, por lo que las negociaciones de paz avanzaron más deprisa, firmando la Paz de Londres en abril de 1604 .

\section{AGRADECIMIENTOS}

La edición de este trabajo ha sido posible gracias a la ayuda del Programa de Grupos de Potencial Crecemento concedida por la Consellería de Cultura, Educación e Universidade da Xunta de Galicia al GI-1921 de la USC (Referencia: GPC, ED 431B 2021/06). 


\section{Bibliografía}

Aerts, Erik, BAelde, Michel y Coppens, Herman (1995), Les institutions du gouvernement central des Pays-Bas habsbourgeois (1482-1795), Bruxelles, Archives Génerales du Royaume.

Adams, Simon (2004), «Elisabeth I and the sovereignty of the Netherlands, 15761585», Transactions of the Royal Historical Society, 14, pp. 309-319. <https:// doi.org/10.1017/S0080440104000118>.

Adams, Simon (1998), «The decision to intervene: England and the United Provinces 1584-1585», en Congreso Internacional Felipe II (1598-1998), Europa dividida, la monarquía católica de Felipe II, tomo 1, pp. 19-31, Madrid, Parteluz.

ANDREws, Kenneth R. (1964), Elizabethan privateering: English privateering during the Spanish war, 1585-1603, Cambridge, Cambridge University Press.

Anónimo (1603), Prives devis, entre le marquis Spínola et son frère Federicq, pour l'agrandissement de leur maison, La Haya.

ArAnda, Gabriel (1693), Inmortal memoria del eminentísimo señor [...] D. Agustín Spínola, cardinal de la iglesia de Roma, Sevilla, Thomas Lopez de Haro, Impresor y mercader de Libros.

Armitage, David (2000), The Ideological Origins of the British Empire, Cambridge, Cambridge University Press. < https://doi.org/10.1017/CBO9780511755965>.

BARADO, Francisco (1889), Museo militar: historia del Ejército español: armas, uniformes, sistemas de combate, instituciones, organización del mismo desde los tiempos más remotos hasta nuestros días, vol. 3, Barcelona, Imprenta Manuel Soler.

Barozzi, Nicolo y Berchet, Guglielmo (1856, eds.), Relazioni degli Stati Europei, Lette al Senato dagli Ambasciatori Veneti nel secolo Decimosettimo. Serie I - Spagna, vol. I, Serie Relazione di Spagna di Girolamo (sic.), Soranzo, Venezia.

Bertini, Giuseppe (2018), «La nazione italiana nell’ esercito di Alessandro Farnese nei Paessi Bassi: Nuove prospettive», Philostrato, Revista de Historia y Arte, pp. 258-295. <https://doi.org/0.25293/philostrato.2018.10>

Bolsée, Jacques (1991), Inventaire des Archives des Conseils et Sièges d'Amirauté, Bruxelles, Archives Générales du Royaume.

Borman, Tracy (1997), «Untying the Knot? The Survival of the Anglo-Dutch Alliance, 1587-1597», European History Quarterly, 27 (3), July, pp. 307-337. <https://doi.org/10.1177\%2F026569149702700301>. 
Brown, Rawdon (1897, ed.), Calendar of State Papers Relating to English Affairs in the Archives of Venice, 1592-1603, vol. 9, Originally published by Her Majesty's Stationery Office, London.

Carpentier, Bastien y Priotti, Jean-Philippe (2015), «La forge instable d'une domination. Les Doria, Gênes et la monarchie hispanique (1560-1606)», en Prioritti, Jean-Philippe (dir.), Identités et territoires dans les Mondes Hispaniques, Rennes, PUR, pp. 75-96, <https://doi.org/10.4000/books.pur.90139>.

Casoni, Filippo (1691), Vita del marchese Ambrogio Spinola, l'espugnatore delle piazze, Génova, per Antonio Casamara.

Cerezo Martínez, Ricardo (1989), Las Armadas de Felipe II historia de la Marina española, Madrid, Editorial San Martin.

Choart De Buzanval, Paul (1846), Lettres Et Négociations De Paul Choart, Seigneur De Buzanval, Ambassadeur Ordinaire De Henri IV En Hollande, Et De François D'Aerssen Agent Des Provinces-Unies En France. (1598, 1599.), Suivies de quelques pièces diplomatique concernant les années 1593-1596, et 1602-1606. Leide, S. et J. Luchtmans.

Corbett, Julian Stafford (1900), The successors of Drake, London, Longmans Green.

Corbett, Julian Stafford (1917), Drake and the Tudor navy, vol. 1, London, Longmans.

Dugniolle, Jean Françoise (1877), Le jeton historique des dix-sept provinces des Pays-Bas, Bruxelles, F. Gobbaerts, imprimeur du roi.

Dunthorne, Hugh (2013), Britain and the Dutch Revolt, 1560-1700, Cambridge, Cambridge University Press. <https://doi.org/10.1017/CBO9781139046138>.

Duquenne, Frédéric (1998), «Traité de Plessis-lès-Tours entre les Pays-Bas et le duc d'Anjou, 19 Septembre 1580 », en L'entreprise du duc d'Anjou aux Pays-Bas de 1580 à 1584: les responsabilités d'un échec à partager, Villeneuve-d'Ascq, Presses Universitaires du Septentrion. <https://dutchrevolt.leiden.edu/Fran\%C3\%A7ais/sources/Pages/15800919fra.aspx>.

EBBen, Maurits (1998), «Felipe II y la rebelión neerlandesa en la historiografía holandesa de 1830 hasta 1960», en Congreso Internacional Felipe II (1598-1998), Europa dividida, la monarquía católica de Felipe II, t. 4, pp. 77-88, Madrid, Parteluz.

Esteban Estringana, Alicia (2002a), «Administración militar y negocio en los Países Bajos católicos, siglo XVII», en Crespo Solana, Ana y Herrero Sánchez, Manuel (coords.), España y las 17 provincias de los Países Bajos. Una revisión historiográfica, pp. 65-100, Córdoba. 
Esteban Estringana, Alicia (2002b), Guerra y finanzas en los Países Bajos católicos. De Farnesio a Spínola (1597-1630), Madrid, Ediciones del Laberinto.

Estrada, Famiano (1701), Guerras de Flandes desde la muerte de Carlos V hasta el gobierno de Alejandro Farnesio. De las cosas que hizo en Francia Alejandro Farnese, Libro III, Amberes, Henrico y Cornelio Verdussen.

FAGEL, Raymond (2001), «El camino español por mar: los soldados españoles en los Países Bajos durante la época de Carlos V», en Martínez Millán, Jose (coord.), Congreso Internacional Carlos V y la quiebra del humanismo político en Europa (1530-1558), vol. 1, pp. 363-376, Madrid, Sociedad Estatal para la conmemoración de los centenarios de Felipe II y Carlos V.

FERnÁNDEZ Álvarez, Manuel (1947), «Orígenes de la rivalidad naval hispano-inglesa en el siglo XVI», Revista de Indias, 8, pp. 311-369.

Fernández Duro, Cesáreo (1973), Armada española desde la unión de los reinos de Castilla y Aragón, Madrid, Museo Naval.

Fernández-Armesto, Felipe (1988), The Spanish Armada: The Experience of War in 1588, Oxford, Oxford Unversity Press.

Francis, Clare (1981), The commanding sea, London, BBC and Pelham.

García Hernán, David (1989), «El IV Centenario de la Armada contra Inglaterra. Balance historiográfico», Cuadernos de Historia Moderna, 10, pp. 163-182.

Gasch-Tomás, Jose Luis, Trápaga, Koldo y Trindade, Ana Rita (2017), «Shipbuilding in times of war: Contracts for the construction of ships and provision of supplies in the Spanish Empire in the early seventeenth century», The International Journal of Maritime History, 29 (1), pp. 187-192, <https://doi. org/10.1177/0843871416679124>.

Gelabert GonzÁlez, Juan Eloy (2007), «Entre ‘embargo general’ y 'libre comercio'. Las relaciones mercantiles entre Francia y España de 1598 a 1609», Obradoiro de Historia Moderna, 16, pp. 65-90. <https://doi.org/10.15304/ohm.16.539>.

Gelabert GonzÁlez, Juan Eloy (2009), «Los Spínola en Flandes al servicio de Felipe III (1598-1607)», en Cavaciocchi, Simonetta (coord.), La famiglia nell'economia europea, secoli XIII-XVIII [Atti delle Settimane F. Datini], Prato, Firenze University Press, pp. 1000-1015.

Goodman, David (2003), Spanish naval power, 1589-1665: reconstruction and defeat. Cambridge, Cambridge University Press. <https://doi.org/10.3138/ cjh.33.1.96>.

Gorrochategui, Luis (2020), Contra Armada, la mayor victoria de España sobre Inglaterra. Barcelona, Planeta. 
Graham, Winston (1972), The Spanish Armadas, London, Fontana.

Gray, Randal (1978), «Spinola's Galleys in the Narrow Seas, 1599-1603», The Mariner's Mirror, 64 (1), pp. 71-83. <https://doi.org/10.1080/00253359.1978.10 659067>.

Harding, Christopher (2006), «Hostis Humani Generis»: The Pirate as Outlaw in the Early Modern Law of the Sea», en Claire Jowitt (ed.), Pirates? The Politics of Plunder 1550-1650, Basingstoke, Palgrave McMillan, pp. 20-38. <https://doi. org/10.1057/9780230627642_2>.

Herrera, Antonio de (s.f.), «Discurso y tratado que los grandes capitanes por diferentes caminos hacen grande y memorables hechos y hazañas», De las varias epístolas discursos y tratados de Antonio de Herrera [BNE, MSS. 1035, f. $67 \mathrm{v}-73 \mathrm{v}]$.

Historical Manuscripts Commission (1904), Calendar of the manuscripts of the [...] marquis of Salisbury [...] preserved at Hatfield House, part 10, London.

Hortal MuÑoz, José Eloy (2008), «La visión de un ministro 'castellanista' sobre la situación de los Países Bajos al final del siglo XVI: los 'advertimientos' de Esteban de Ibarra», Bulletin de la Commission royale d'Histoire, 174 (11), pp. 89-166. <https://doi.org/10.3406/bcrh.2008.1069>.

Hume, Martin A. S. (1896), «The counter-armada of 1589», The Year after de the Armada and other historical studies, London.

Hume, Martin A. S. (1901), Treason and Plot: Struggles for Catholic Supremacy in the Last Years of Queen Elizabeth, New York, Appleton \& company.

ILLIK, Peter (2018), «The fall of the Spanish armada: historiography, identity and reception», West Bohemian Historical Review, n. 1, pp. 1-17. < http://hdl.handle. net/11025/34482>.

Jurien de La Gravière, Edmond (1891), Le siège de La Rochelle: les origines de la marine française et la tactique naturelle, Paris, Librairie de Firmin Didot et Cia.

KuIngenstein, L. (1910), The great infant Isabel, sovereign of the Netherlands, New York, Putnam.

LAUER, A. Robert (2019), «Diplomacia y ética política: textos prudenciales de Felipe II, Juan de Mariana y Joseph Creswell durante las Guerras de Religión de Francia (1562-1598) y la Guerra Anglo -Española (1585-1604)», Hipogrifo, 7 (1), pp. 615-631, <http://dx.doi.org/10.13035/H.2019.07.01.46>.

Lemaire, Louis (1934), «L'amirauté de Dunkerque, 1579-1791», Le Bulletin de l’Union Faulconnier, 31, pp. 155-241. 
Lo BAsso, Luca (2007), «Gli Asentisti del re. L'esercizio privato della guerra nelle strategie economiche dei Genovesi (1528-1716)», en Cancila, Rosella (ed.), Mediterraneo in armi (secc. XV-XVIII), Palermo, Associazione Mediterranea, pp. 397-428.

Lonchay, Henri y Cuvelier, Joseph (1923), Correspondance de la cour d'Espagne sur les affaires des Pays-Bas au XVII siècle, Brusseles Librairie Kiessling et Cia, t. 1.

MacCaffrey, Wallace Trevethic (1981), Queen Elizabeth and the Making of Policy, 1572-1588, New Jersey, Princeton University Press. <https://doi. org/10.1515/9781400855995>.

Maland, David (1980), Europe at war 1600-1650, London, The Macmillan Press. $<$ https://doi.org/10.1007/978-1-349-16244-4>.

Martínez Millán, Jose y de Carlos Morales, Carlos (1998, dirs.), Felipe II (15271598): la configuración de la Monarquía Hispana, Valladolid, Junta de Castilla y León.

MotLey, John Lothrop (1868), The rise of the Dutch Republic: a History, London, Routledge.

Novoa, Matías de (1875), Memorias de Matías Novoa conocidas hasta ahora bajo el título de Historia de Felipe III, CODOIN, Madrid, vols. LX-LXI.

OOSTERHOFF, Frederika Gezina (1967), The Earl of Leicester's governorship of the Netherlands, 1586-1587, London, University of London.

Ortega y Medina, Juan A. (1994), El conflicto anglo español por el dominio oceánico, México, Universidad Nacional Autonoma de México.

Otero Lana, Enrique (2005), «El corso del Flandes español como factor de guerra económica», Studia Historica: Historia Moderna, 27, pp. 111-133.

PARKER, Geoffrey (1976), «If the Armada had landed», History, 61-203, pp. 358-368. $<$ https://doi-org.ubu-es.idm.oclc.org/10.1111/j.1468-229X.1976.tb01347.x>.

PARKer, Geoffrey (2002), «The Place of Tudor England in the Messianic Vision of Philip II», Transactions of the Royal Historical Society, 12, pp. 167-221. <https://doi.org/10.1017/S0080440102000063>.

Parker, Geoffrey y Martin, Colin (1999), The Spanish Armada. Revised edition, Manchester, Mandolin.

Pollentier, F. (1959), «De hervorming van de Admiraliteit op het einde van de XVIe eeuw met betrekking tot Duinkerken», Handelingen van het Genootschap voor Geschiedenis, 96.3-4, pp. 157-177. <https://doi.org/10.21825/hvgg.v96i34.4210>. 
Retortillo Atienza, Asunción (2017), Ambrosio Spinola de Génova a Ostende, 1569-1604, Madrid, Ministerio de Defensa.

Retortillo Atienza, Asunción y Borreguero Beltrán, Cristina (2018), «La sua professione fu di soldato: italianos en el ejército de los Austrias», Rafael Torres Sánchez (coord.), Studium, magisterium et amicitia: homenaje al profesor Agustín González Enciso. Pamplona, EUNATE, pp. 187-200.

Riaño Lozano, Fernando (1999), Los medios navales de Alejandro Farnesio, 15871588, Madrid, Naval.

Rizzo, Mario (1998), «Milano e le forze del Principe: Agenti, relazioni e risorse per la difesa dell'imperio di Filip II», en Congreso Internacional Felipe II (15981998), Europa dividida, la monarquía católica de Felipe II, Madrid, Parteluz, tomo 1, vol. 2, pp. 731-766.

Roco de CAmpofrío, Juan (1973), España en Flandes, dieciocho años de gobierno del archiduque. Madrid, Ayuntamiento de Alcantara, [edición original, $1565]$.

Rodríguez Grajera, Alfonso (2019), «Pureza y fidelidad versus corrupción y cohecho. el ejemplo del embargo general de 1598», Obradoiro de Historia Moderna, 28, pp. 219-241. <https://doi.org/10.15304/ohm.28.5775>.

Rodríguez Villa, Antonio (1904), Ambrosio Spínola, $1^{\text {er }}$ marques de los Balbases, Madrid, Establecimiento tipográfico de Fortanet.

Rodríguez Villa, Antonio (1906), Correspondencia de la Infanta archiduquesa Doña Isabel Clara Eugenia de Austria con el Duque de Lerma y otros personajes, Madrid, Establecimiento tipográfico de Fortanet.

SaAvedra Vázquez, María del Carmen Saavedra (1989), María Pita y la defensa de La Coruña en 1589, A Coruña, Editorial D.L.

SaAvedra VÁzquez, María del Carmen Saavedra (1998), «El corsarismo inglés en Galicia: los ataques a Vigo y A Coruña y la militarización del reino», en Antonio Eiras Roel (coord.), El reino de Galicia en la Monarquía de Felipe II, Santiago de Compostela, Xunta de Galicia, pp.115-137.

SAInT-Prest, Jean Yves de (1720), Histoire des traités de paix: et autres negociations du dix-septième siècle, depuis la paix de Vervins, jusqu'à la paix de Nimegue..., Amsterdam, J. F. Bernard.

Saiz Cidoncha, Carlos (1985), Historia de la piratería en América española, Madrid, San Martín.

Sanz Camañes, Porfirio (2004), «Las relaciones entre el Teatro y la Política en la creación de imágenes y propaganda sobre Flandes en la España del Barroco», 
en VII Reunión Científica de la Fundación Española de Historia Moderna, Albacete, Ediciones de la Universidad de Castilla-La Mancha, pp. 957-989.

Sanz Camañes, Porfirio (2007), «España ante las paces del Norte a comienzos del siglo XVII: del Tratado de Londres a la Tregua de Amberes», Cuadernos de Historia de España, 81, p. 113-134.

Sanz Camañes, Porfirio (2012), Los ecos de la Armada: España, Inglaterra y la estabilidad del Norte (1585-1660), Madrid, Sílex.

SAnz CAmañes, Porfirio (2017), «Balance Historiográfico. Armadas y flotas en la España de los Austrias. Una relectura crítica», Vínculos de Historia, 6, pp. 405417. <https://doi.org/10.18239/vdh.v0i6.285>.

SHAw, William A. (1936, ed.), «The financial and political relationships between Elisabeth, the United Provinces, and the occupation of Flushing, Report on the manuscripts of Lord De l'Isle \& Dudley preserved at Penhurst Place», Historical Manuscripts Commission, volume 3.

Sicking, Louis (2017), El Almirantazgo y la Armada de los Países Bajos durante los reinados de Felipe Iy Carlos V, Santander, Universidad de Cantabria. $<$ https:// doi.org/10.22429/Euc2017.035>.

Sicking, Louis (2019), Neptune and the Netherlands: State, Economy, and War at Sea in the Renaissance, Leiden-Boston, Brill.

Stradling, Robert A. (1992), La Armada de Flandes, política naval española y guerra europea, 1568-1668, Madrid, Cátedra, <https://doi.org/10.1017/ CBO9780511470677>.

TEnACE, Edward (2003), «A strategy of reaction: The Armadas of 1596 and 1597 and the Spanish struggle for European hegemony», The English Historical Review, 118-478, pp. 855-882. <https://doi.org/10.1093/ehr/118.478.855>.

van BRuYsSel, Ernest (1864), Histoire du commerce et de la marine en Belgique, Paris, Librairie Internationale, vol. 3.

Villiers, Patrick (2000), Les corsaires du littoral: Dunkerque, Calais, Boulogne, de Philippe II à Louis XIV (1568-1713), Villeneuve d'Ascq, Presses Université du Septentrion. <https://doi.org/10.4000/books.septentrion.49320>.

Wagner, John A. (2019), Document's of Shakespeare's England, Santa Barbara, California, ABC-CLIO.

Wallace, Malcom William. (1916), «A declaration of the Causes Moving the Queen of England to give Aid to the defence of the people afflicted and oppressed in the Low Countries», en The life of Sir Philip Sidney, Cambridge, Cambridge University Press. 
WARnER, Oliver (1963), Great Sea battles, London, Spring Books.

Wernham, Richard (1994), The Return of the Armadas: The Last Years of the Elizabethan War against Spain 1595-1603, Oxford, Clarendon Press. 